\title{
Enhancement of human cancer cell radiosensitivity by conjugated eicosapentaenoic acid - a mammalian DNA polymerase inhibitor
}

\author{
YUKO KUMAMOTO-YONEZAWA ${ }^{1}$, RYOHEI SASAKI ${ }^{2}$, YOKO SUZUKI ${ }^{2}$, YUKI MATSUI ${ }^{1}$, TAKAHIKO HADA ${ }^{3}$, \\ KEISUKE URYU ${ }^{3}$, KAZURO SUGIMURA ${ }^{2}$, HIROMI YOSHIDA ${ }^{1,4}$ and YOSHIYUKI MIZUSHINA ${ }^{1,4}$ \\ ${ }^{1}$ Laboratory of Food and Nutritional Sciences, Department of Nutritional Science, Kobe-Gakuin University, Nishi-ku, Kobe, \\ Hyogo 651-2180; ${ }^{2}$ Division of Radiology, Kobe University Graduate School of Medicine, Chuou-ku Kobe, Hyogo 650-0017; \\ ${ }^{3}$ Department of Research and Development, Bizen Chemical Co. Ltd., Akaiwa, Okayama 709-0716; ${ }^{4}$ Cooperative Research \\ Center of Life Sciences, Kobe-Gakuin University, Chuou-ku, Kobe, Hyogo 650-8586, Japan
}

Received September 23, 2009; Accepted November 6, 2009

DOI: 10.3892/ijo_00000532

\begin{abstract}
We previously found that conjugated eicosapentaenoic acid (cEPA) selectively inhibited the activities of mammalian DNA polymerases (pols), and suppressed human cancer cell growth. The aim of the present study was to evaluate the efficacy of concurrent radiation with cEPA in a human colon carcinoma cell line, HCT 116. Furthermore, we examined the most effective timing of irradiation. The postirradiation addition of cEPA significantly enhanced HCT116 cell radiosensitivity by decreasing the expression of pols $\beta, \delta$ and $\varepsilon$, increasing damaged DNA, such as DNA double-strand breaks, inhibiting clonogenic survival, and inducing apoptosis. However, cells treated by pre-irradiation addition of cEPA did not influence radiosensitive survival and radiation-induced apoptosis. cEPA inhibited the activities of pols needed for DNA repair, thereby DNA damage must be augmented by cEPA and irradiation. These results suggested that the combination of inhibitors of DNA repair-related pols/radiation could be an effective anticancer therapy.
\end{abstract}

Correspondence to: Dr Yoshiyuki Mizushina, Laboratory of Food and Nutritional Sciences, Department of Nutritional Science, KobeGakuin University, Nishi-ku, Kobe, Hyogo 651-2180, Japan

E-mail: mizushin@nutr.kobegakuin.ac.jp

Abbreviations: cEPA, conjugated eicosapentaenoic acid; pol, DNA polymerase (EC 2.7.7.7); DSB, DNA double-strand break; PUFA, polyunsaturated fatty acid; ATR, ataxia-telangiectasia mutated- and Rad3-related protein kinase; MTT, 3-(4,5dimethylthiazol-2-yl)-2,5-diphenyltetrazolium bromide; PCR, polymerase chain reaction

Key words: conjugated eicosapentaenoic acid, DNA polymerase, enzyme inhibitor, radiosensitivity, DNA damage, anticancer therapy

\section{Introduction}

DNA polymerases (pol, i.e., DNA-dependent DNA polymerases, E.C. 2.7.7.7) catalyze the addition of deoxyribonucleotides to the 3'-hydroxyl terminus of primed doublestranded DNA molecules, and are involved in producing vital cellular processes, such as DNA replication, repair and recombination (1). The human genome encodes at least 15 pols to conduct cellular DNA synthesis $(2,3)$. Eukaryotic cells contain three replicative pols $(\alpha, \delta$ and $\varepsilon)$, mitochondrial pol $\gamma$, and at least 13 repair-related pols; $\beta, \delta, \varepsilon, \zeta, \eta, \theta, \iota, \varkappa, \lambda$, $\mu, v$, terminal deoxynucleotidyl transferase (TdT) and REV1 (2-4). Pols have recently emerged as important cellular targets for chemical intervention in the development of anticancer agents.

We have been screening for pol inhibitors from natural products $(5,6)$, and found that mammalian pols $\alpha$ and $\beta$ are inhibited by linear-chain fatty acids with the following characteristics: 1) C18-or more carbon chains, 2) a free carboxylic group, and 3) double bonds of cis-configuration, n-3 polyunsaturated fatty acid (PUFA) having the strongest inhibitory effect of any fatty acid tested $(7,8)$. Eicosapentaenoic acid (EPA; 5Z8Z11Z14Z17Z-20:5) and docosahexanoic acid (DHA; 4Z7Z10Z13Z16Z19Z-22:6), both $n-3$ PUFAs, exert significant inhibitory effects on colon carcinoma cell growth at the primary site and metastases $(9,10)$. PUFA are present at high concentrations in some fish oils, and have been evaluated in various clinical trials in which they have proved to be safe and well tolerated.

Conjugated fatty acids are positional and geometrical isomers with several conjugated double bonds. Fatty acids with conjugated double bonds exist in nature; seaweeds such as red and green algae contain highly n-3 unsaturated conjugated fatty acids, i.e., conjugated eicosapentaenoic acid (cEPA; 5Z7E9E14Z17Z-20:5), bosseopentaenoic acid (5Z8Z10E12E14Z-20:5) and stellaheptaenoic acid (4Z7Z9 E11E13Z16Z19Z-22:7) (11,12). As n-3 PUFAs have been shown to have anticarcinogenic activity, conjugated fatty acids converted from n-3 PUFAs may show higher tumor- 
inhibiting activity than n-3 PUFAs themselves $(13,14)$. We previously realized the importance of the two classes of $n-3$ PUFA; EPA and DHA, normal and conjugated, and the inhibitory effect of cEPA on pols was stronger than that of EPA, DHA and cDHA (15). Furthermore, cEPA regulates the cell cycle by DNA damage-response proteins, including the ataxia-telangiectasia mutated- and Rad3-related protein kinase (ATR)-Chk1/2 pathway without influencing the proliferation of normal cells $(16,17)$.

Radiotherapy is one of the most commonly used therapeutic modalities in cancer treatment. Radiation ionizes the molecules of tumor cells, and damages their DNA (18). These effects are not limited to tumor cells but also affect normal cells within the tumor stroma $(19,20)$. The cytotoxicity of radiation is mostly mediated through the generation of DNA double-strand breaks (DSBs) as demonstrated by the radiosensitivity of cells and organisms defective in the machinery of DSB repair (21-23). Ataxiatelangiectasia mutated (ATM) protein kinase is a component of these pathways and integrates the cellular response to damage by phosphorylating some key proteins involved in cell cycle regulation and DSB repair $(24,25)$. Thus, cEPA seems to be an ideal model for the study not only of the molecular mechanisms that inhibit pol activity for the development of new anticancer drugs, but also of cellular proliferation processes such as DNA replication and repair of damaged DNA, such as DSBs, by X-ray irradiation.

In the present study, we investigated whether the radiosensitizing effect of cEPA on human colon carcinoma HCT116 cells and further analyzed the mechanisms of radiosensitization by cEPA.

\section{Materials and methods}

Materials. EPA was purchased from Nu-Chek Prep Inc. (Elysian, MN, USA). Nucleotides and chemically synthesized DNA template primers, such as poly(dA) and oligo $(\mathrm{dT})_{12-18}$, and radioisotope reagents, such as $\left[{ }^{3} \mathrm{H}\right]$-dTTP (2'-deoxythymidine 5 '-triphosphate) $(43 \mathrm{Ci} / \mathrm{mmol})$, were purchased from GE Healthcare Bio-Science Corp. (Piscataway, NJ, USA). All other reagents were of analytical grade and purchased from Nacalai Tesque Inc. (Kyoto, Japan).

Preparation of cEPA by alkaline treatment. cEPA was prepared by alkaline treatment following the AOAC method with slight modifications (26). Potassium hydroxide at a concentration of 6.6 or $21 \%(\mathrm{w} / \mathrm{w})$ in ethylene glycol was prepared and the $\mathrm{KOH}$ solution was bubbled for 5 min with nitrogen gas. EPA $(10 \mathrm{mg})$ was added to $1 \mathrm{ml}$ of $6.6 \%$ or $21 \% \mathrm{KOH}$ solution in a test tube ( $10 \mathrm{ml}$ volume $)$. The mixture was bubbled with nitrogen gas and then screwcapped and allowed to stand for 5 or $10 \mathrm{~min}$ at $180^{\circ} \mathrm{C}$. The reaction mixture was cooled, and $1 \mathrm{ml}$ methanol was added. The mixture was acidified to below pH 2 with $2 \mathrm{ml}$ of $6 \mathrm{~N}$ $\mathrm{HCl}$. After dilution with $2 \mathrm{ml}$ distilled water, the conjugated fatty acid was extracted with $5 \mathrm{ml}$ hexane. The hexane extract was then washed with $3 \mathrm{ml}$ of $30 \%$ methanol and with $3 \mathrm{ml}$ distilled water before being evaporated under a nitrogen gas stream. The conjugated fatty acids were stored at $-20^{\circ} \mathrm{C}$ after being purged with nitrogen gas. UV/VIS spectrophotometric analysis was performed with a Shimadzu UV-2400PC. Spectrophotometric readings confirmed the conjugation of fatty acids of pentaene (345 nm) (27). cEPA was dissolved in dimethyl sulfoxide (DMSO) at various concentrations and sonicated for $30 \mathrm{sec}$.

Cell culture. Human colon carcinoma cell line, HCT116, was a kind gift from Dr Bert Vogelstein (Johns Hopkins University, Baltimore). The cells were maintained in McCoy's 5A medium supplemented with $10 \% \mathrm{FBS}$, sodium bicarbonate $(2 \mathrm{mg} / \mathrm{ml})$ and streptomycin $(100 \mu \mathrm{g} / \mathrm{ml})$ at $37^{\circ} \mathrm{C}$ in a humidified atmosphere of $5 \% \mathrm{CO}_{2} / 95 \%$ air.

MTT (3-(4,5-dimethylthiazol-2-yl)-2,5-diphenyltetrazolium bromide) assay. HCT 116 cells were trypsinized and resuspended in McCoy's 5A medium with 10\% FBS, and $5 \times 10^{3}$ cells were seeded in 96-well tissue culture plates for $24 \mathrm{~h}$. The cells were then stimulated with different concentrations of cEPA containing DMSO of final concentration of $1 \%$ for $24 \mathrm{~h}$. After treatment, MTT solution was added (final concentration $0.5 \mathrm{mg} / \mathrm{ml} \mathrm{MTT}$ in PBS) for $3 \mathrm{~h} \mathrm{(28).} \mathrm{The}$ medium was discarded and the cells were lysed in acidified 2-propanol. Absorbance was measured at $570 \mathrm{~nm}$ on a microplate reader (Molecular Devices, Sunnyvale, CA, USA).

DNA polymerase assay of the cell extract. HCT116 cells were plated at $3 \times 10^{5}$ into a $100-\mathrm{mm}$ culture dish with or without $30 \mu \mathrm{M}$ of cEPA. After $24 \mathrm{~h}$ incubation, the cells were washed with PBS, collected by centrifugation, and the pellets were sonicated for $3 \mathrm{~min}$ in lysis buffer $(10 \mathrm{mM}$ $\mathrm{NaCl}, 10 \mathrm{mM}$ Tris-HCl, 1 mM EDTA, $1.5 \mathrm{mM} \mathrm{MgCl}$, $1 \mathrm{mM}$ dithiothreitol, $7.5 \%$ glycerol, $1 \%$ Triton $\mathrm{X}$ ). The pol activity of the cell extract was measured as described previously $(7,8)$. Poly $(d A) / o l i g o(d T)_{12-18}$ and dTTP were used as the DNA template-primer and nucleotide substrate, respectively. One unit of pol activity was defined as the amount of enzyme that catalyzed the incorporation of $1 \mathrm{nmol}$ dNTP (2'-deoxyribonucleotide 5'-triphosphate, i.e. dTTP) into the synthetic DNA template-primers [i.e. poly $(\mathrm{dA}) / \mathrm{oligo}(\mathrm{dT})_{12-18}, \mathrm{~A} / \mathrm{T}=2 / 1$ ] in $60 \mathrm{~min}$ at $37^{\circ} \mathrm{C}$ under normal reaction conditions for the enzyme $(7,8)$.

X-ray irradiation. Cultures of HCT116 cells were irradiated using an X-ray irradiator (MBR-1505R2; Hitachi Medico, Tokyo, Japan) at a dose rate of $7.8 \mathrm{~Gy} / \mathrm{min}$. Dosimetry was carried out using an ionization chamber connected to an electrometer system.

Real-time PCR analysis. Real-time polymerase chain reaction (PCR) analyses were conducted using standard assays according to Heintel et al (29). HCT116 cells were pre-cultured for $24 \mathrm{~h}$, treated with or without $30 \mu \mathrm{M}$ cEPA for $24 \mathrm{~h}$, radiated at $8 \mathrm{~Gy} \mathrm{X}$-ray and subsequently incubated for $10 \mathrm{~min}$. Total RNA was isolated from treated HCT116 cells using the RNeasy mini kit (Qiagen, Hilden, Germany). The extracted total RNA was reverse-transcribed into singlestranded cDNA using a High Capacity RNA-to-cDNA Kit (Applied Biosystems, Warrington, UK). Aliquots of cDNA were used as templates for real-time PCR reactions containing 
A

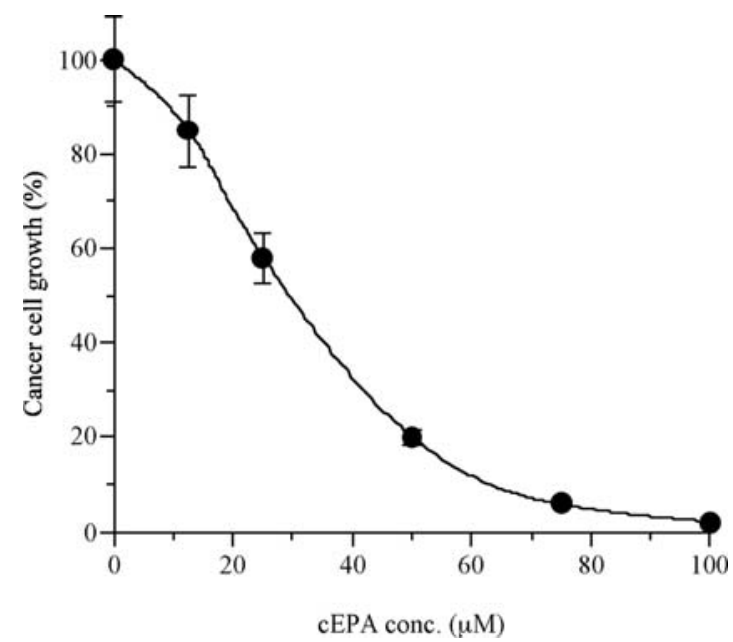

B



Figure 1. Inhibitory effect of cEPA on the proliferation of HCT116 cells. (A) Dose-response curves of growth inhibition on human colon carcinoma cell line, HCT116 incubated with various concentrations of cEPA for $24 \mathrm{~h}$. Cell proliferation was determined by MTT assay (28). Values are shown as the means \pm SEM of three independent experiments. (B) Total pol activity of cell-free extracts from HCT116 cells incubated with cEPA. HCT116 cells (3x10 5 cells) were incubated with the indicated concentrations of cEPA for $24 \mathrm{~h}$. From the cell extracts, total pol activity was measured as described previously (7,8). One unit of pol activity is defined as the amount that catalyzes the incorporation of $1 \mathrm{nmol}$ dexyribonucleoside triphosphate (i.e., dTTP) into synthetic template-primers [i.e., poly $(\mathrm{dA}) / \mathrm{oligo}(\mathrm{dT})_{12-18}, \mathrm{~A} / \mathrm{T}=2 / 1$ ] at $37^{\circ} \mathrm{C}$ in $60 \mathrm{~min}$. Values are the means $\pm \mathrm{SEM}$ of four independent experiments.

primers of either the target gene or the control. All oligonucleotide primers for the endogenous control (18s rRNA) and the target five pol genes (i.e., human pols $\alpha, \beta, \delta, \varepsilon$ and $\lambda$ ) were synthesized by Applied Biosystems, and were as follows: accession number (common name), 4308329 (18s rRNA); Hs00415835 (polymerase $\alpha$ ); Hs00160263 (polymerase $\beta$ ); Hs00172491 (polymerase $\delta$ ); Hs00173030 (polymerase $\varepsilon$ ); Hs00203191 (polymerase $\lambda$ ). Each amplification was performed using first-strand cDNA with TaqMan First Universal PCR Master Mix (Applied Biosystems). The PCR reactions, TaqMan analyses, and subsequent calculations were performed with the StepOne ${ }^{\mathrm{TM}}$ Real-Time PCR System (Applied Biosystems) according to the manufacturer's instructions. All reactions were performed in a $20 \mu 1$ reaction volume in triplicate. The mRNA expression level was determined using the $2^{-\Delta C \mathrm{~T}}$ method.

Comet assay. To assess the generation of DSB in cultured cancer cells, the standard protocol for the single-cell electrophoresis (comet) preparation and analysis was adopted (30). Briefly, HCT116 cells were seeded, cultured in 6-well plates for $24 \mathrm{~h}$, and then incubated with or without $30 \mu \mathrm{M}$ cEPA for $30 \mathrm{~min}$. The plates were immediately radiated with $8 \mathrm{~Gy}$ $\mathrm{X}$-ray. After the irradiated cells with or without cEPA were harvested for 0,15 and $30 \mathrm{~min}$, the cells were lysed in neutral (pH 7.0) buffer, electophoresed, and stained following the manufacturer's instructions. For evaluation of DNA damage, 500 cells/subject were analyzed at x400 magnification under a fluorescent microscope (BX51N-34-FL; Olympus Corp., Tokyo, Japan) equipped with a $540 \mathrm{~nm}$ excitation filter and a $590 \mathrm{~nm}$ barrier filter. The mean \% tail DNA was analyzed using the imager Rainbow Star (RBS-111; Toyobo Co., Tokyo, Japan).

Radiation clonogenic assay. Survival following radiation exposure was defined as the ability of cells to maintain clonogenic capacity and form colonies. After HCT116 cells were treated with vehicle (DMSO) alone, cEPA alone, irradiation alone, or cEPA plus irradiation for $48 \mathrm{~h}$, the cells were trypsinized, counted, and appropriate dilutions were made. The appropriate number of cells was plated in fresh medium without cEPA for colony formation into $100 \mathrm{~mm}$ dishes. After incubation intervals of 14 days, the colonies (containing $\geq 50$ cells) were stained with methylene blue, and the numbers of colonies were counted. The surviving fraction (SF) was calculated as a ratio of the number of colonies to the number of cells plated (plating efficiency) divided by the same ratio calculated for the non-irradiated group. Experiments were performed in duplicate.

Assessment of apoptosis by annexin $V$ staining. Exactly $48 \mathrm{~h}$ after treatment with cEPA $(30 \mu \mathrm{M})$ alone, irradiation (8 Gy) alone, or cEPA/radiation combination, HCT 116 cells were harvested, and then apoptotic cells were detected by annexin $\mathrm{V}$ staining using a commercially available kit (PharMingen Annexin V-FITC Apoptosis Detection Kit I; BD Biosciences, San Jose, CA, USA) according to the manufacturer's instructions. The stained cells, which are apoptotic, were analyzed using a FACSCanto II flow cytometer in combination with FACSDiVa software (BD Biosciences).

\section{Results}

The effect of cEPA on cellular growth and DNA polymerase activity. First, to determine the effects of cEPA on cultured human cancer cells, we tested their influence on cell growth in human colon carcinoma HCT116 cells. cEPA efficiently inhibited cell growth in a dose-dependent manner, and the $\mathrm{LD}_{50}$ value was $30.1 \mu \mathrm{M}$ for $24 \mathrm{~h}$ incubation (Fig. 1). The total pol activity of the HCT116 cell extract, which was treated with cEPA for $24 \mathrm{~h}$, was lower than that of non-treated cells (Fig. 1B). The enzyme activity was dose-dependently 


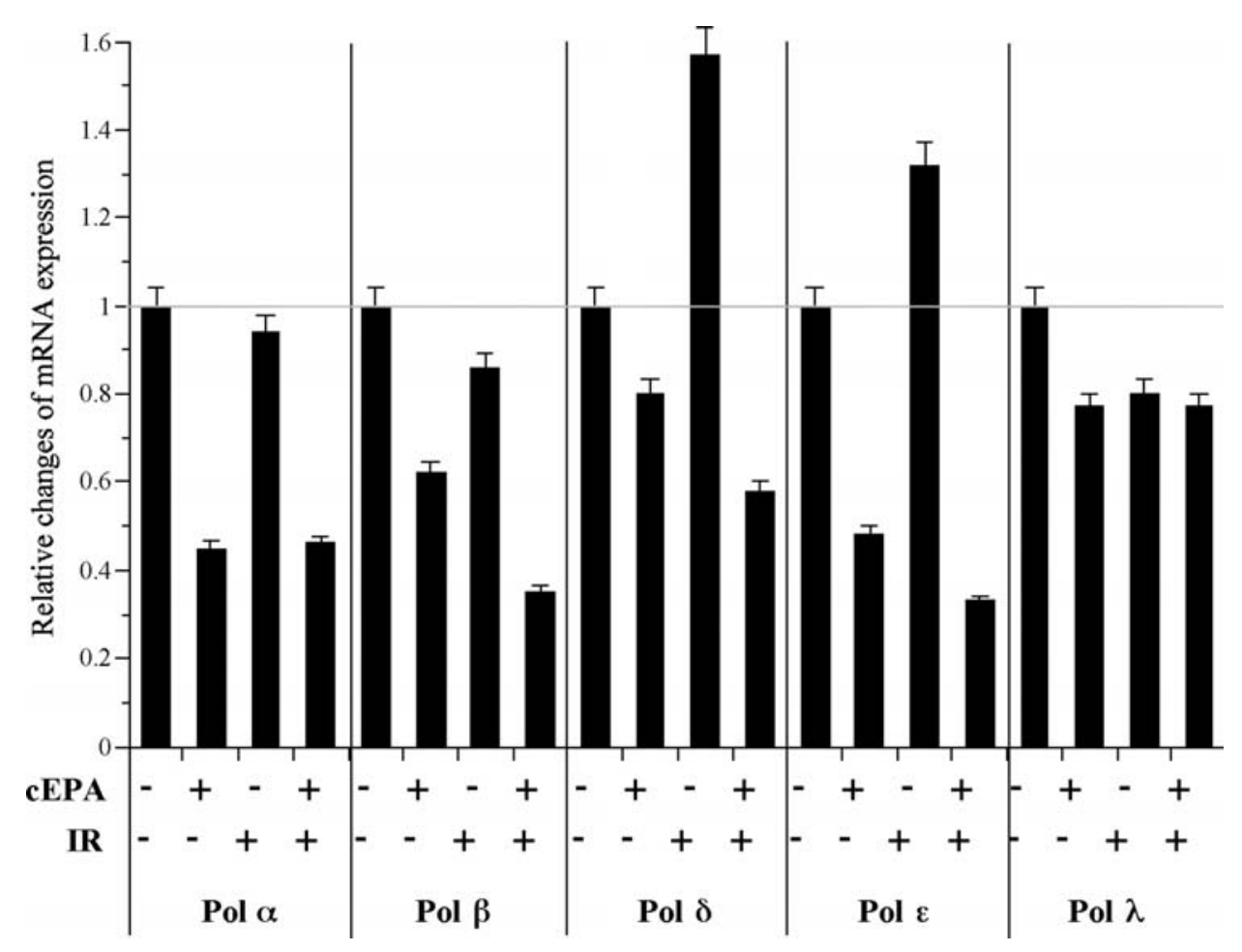

Figure 2. Regulation of pol expression in HCT116 cells by combining cEPA and X-ray radiation. Human colon carcinoma cells (HCT116 cells) were precultured for $24 \mathrm{~h}$, treated with or without $30 \mu \mathrm{M}$ cEPA for $24 \mathrm{~h}$, radiated at $8 \mathrm{~Gy} \mathrm{X}$-ray, and subsequently incubated for 10 min. mRNA was extracted and subjected to real-time PCR as described in Materials and methods. The rate of mRNA expression in both non-treated cEPA and non-irradiated cells (i.e., control) is 1.0. IR is X-ray irradiation. Values are the means \pm SEM of three independent experiments.

decreased with an increase in the concentrations of cEPA, and the inhibitory effect of cEPA on cell growth showed the same tendency as that on pol activity in the cells (Fig. 1). Since we previously reported that cEPA selectively inhibited the activities of purified mammalian pols in vitro with $\mathrm{IC}_{50}$ values of 11.0-31.8 $\mu \mathrm{M}(31)$, the inhibited enzyme by cEPA in the HCT116 cell extract may consist of both DNA replicative pols (i.e., pols $\alpha, \delta$ and $\varepsilon$ ) and DNA repair-related pols (i.e., pols $\beta, \delta, \varepsilon$ and $\lambda$ ). cEPA was more cytotoxic than normal EPA to HCT116 cells, and this tendency of cell growth inhibition was the same as the inhibitory effect of mammalian pols (data not shown).

Effect on expression of pols in HCT116 cells treated with cEPA. Next, we investigated in more detail the effect of cEPA as a selective mammalian pol inhibitor on HCT116 proliferating cells when combined with X-ray radiation. We examined whether the inhibitory activity of pols by $30 \mu \mathrm{M}$ cEPA/8 Gy radiation combination was associated with the expression of mRNA of pols using real-time PCR. As shown in Fig. 2, $30 \mu \mathrm{M}$ cEPA (i.e., the $\mathrm{LD}_{50}$ value of HCT116 cell growth in Fig. 1A) suppressed the expression of all pols, and especially the mRNA amounts of pols $\alpha$ and $\varepsilon$, which are replicative pols, were less than half against non-treated cEPA (i.e., control). These results suggested that cEPA not only could directly bind to pols and inhibit the activities of pols (31), but also might reduce the expression of pols; therefore, pol inhibition by cEPA must suppress cancer cell proliferation. $\mathrm{X}$-ray radiation-exposed cells strongly increased the mRNA expression level of pols $\delta$ and $\varepsilon$, and slightly decreased the
mRNA expression level of pols $\beta$ and $\lambda$. On the other hand, the expressions of pols $B, \delta$ and $\varepsilon$ in cells treated with a combination of cEPA and radiation were significantly lower than by radiation alone, and the expression level of pol $\varepsilon$, which catalyzes DNA replication and repair, revealed the most reduced one of these pols investigated.

Inhibitory effect of cEPA on the repair activity of damaged $D N A$ by $X$-ray radiation. A critical determinant of radiationinduced lethality is the induction and repair of DNA damage, specifically DSBs (32). To determine the effect of cEPA on DNA damage in irradiated HCT116 cells, we evaluated tailing DNA consisting of DSBs by single-cell electrophoresis (comet) assay in neutral buffer. As shown in Fig. 3, in the cells treated with $30 \mu \mathrm{M}$ cEPA alone, DNA tailing reflecting the formation of DSBs was not observed, suggesting that cEPA does not make DSBs. When cells were exposed to $\mathrm{X}$-rays at $8 \mathrm{~Gy}$ alone, DNA tailing was immediately observed in most cells $(93.5 \pm 7.9 \%)$. DNA tailing disappeared gradually with proceeding incubation period, and the cells bearing DNA tailing decreased to $6.4 \pm 0.6 \%$ at 30 min after irradiation. However, the population of cells bearing DNA tailing, which were treated with a combination of X-rays ( $8 \mathrm{~Gy})$ and cEPA $(30 \mu \mathrm{M})$, remained relatively constant 0,15 and $30 \mathrm{~min}$ after irradiation, and the rate of DNA-damaged cells was $94.6 \pm 8.2 \%$. These results suggest that HCT116 cells have the ability to quickly repair damaged DNA containing DSBs by X-ray irradiation, and cEPA prevents the repair of damaged DNA by inhibiting the activities of repair-related pols, such as pols $\beta, \delta, \varepsilon$ and $\lambda$. 

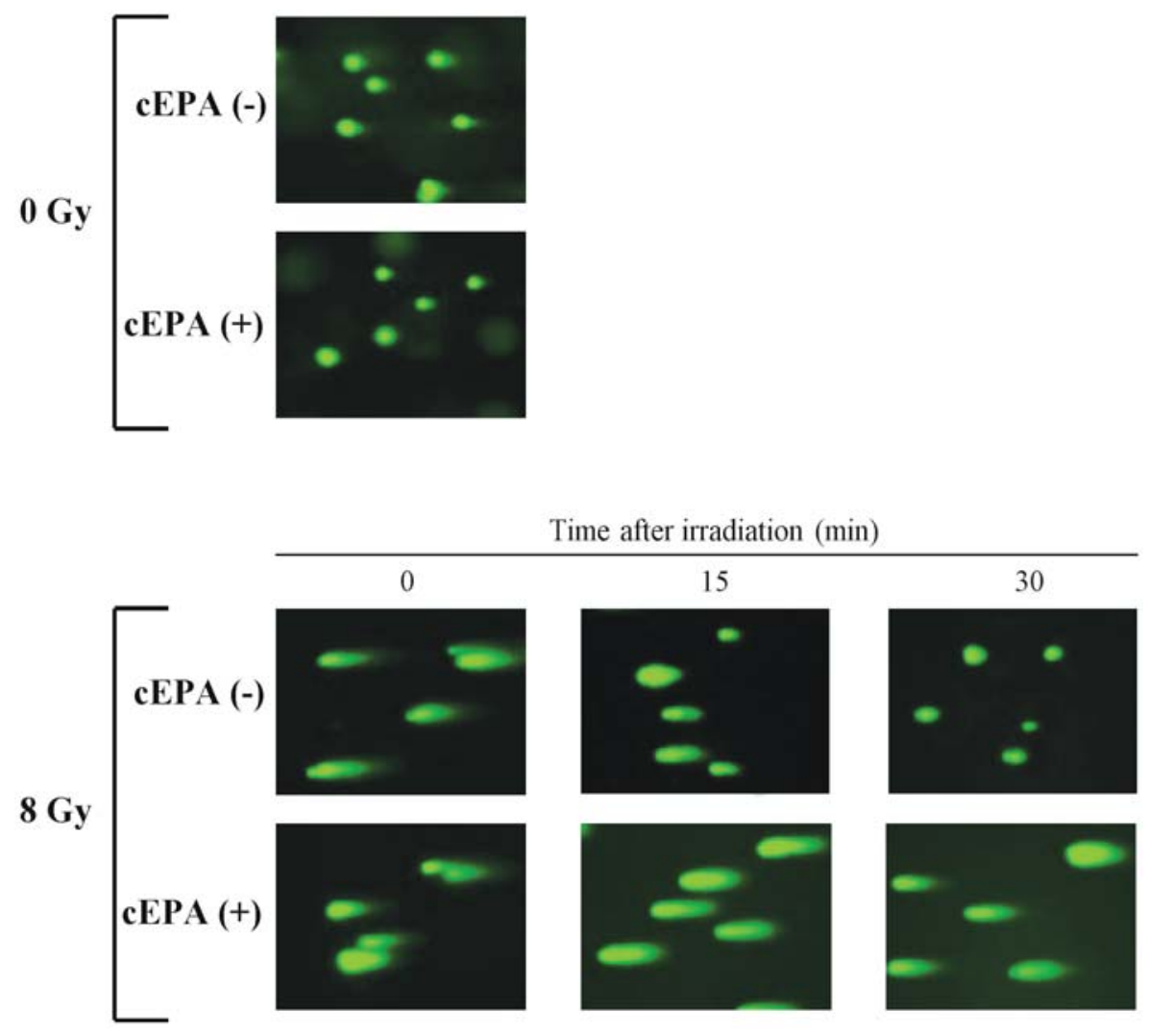

Figure 3. Detection of DNA damage in HCT116 cells by combining cEPA and X-ray radiation. Human colon carcinoma HCT116 cells were incubated with or without $30 \mu \mathrm{M}$ cEPA for $30 \mathrm{~min}$, and then the plates were radiated with $8 \mathrm{~Gy}$ X-ray. After irradiated cells with or without cEPA were harvested at 0 , 15 and $30 \mathrm{~min}$, the cells were lysed in neutral buffer, electophoresed and stained following the manufacturer's instructions. The stained cells are shown by $\mathrm{x} 400$ magnification under a fluorescent microscope.

Effect of cEPA on survival of HCT116 cell radiosensitivity. To determine whether cEPA enhances cellular sensitivity to $\mathrm{X}$-ray radiation, the HCT116 cell line was cultured receiving the combined cEPA/radiation treatment, and then clonogenic survival analysis was performed. HCT116 cells were treated with $1 \%$ DMSO (vehicle control) or $30 \mu \mathrm{M}$ cEPA for $48 \mathrm{~h}$ with 8 Gy of radiation 0,24 or $48 \mathrm{~h}$ after treatment of cEPA [(a), (b) or (c) in Fig. 4A, respectively], and subsequently plated in 100-mm dishes at different densities based on the stringency of treatments. This protocol was used in an attempt to eliminate any effects of trypsinization on postirradiation signaling/recovery processes. The surviving fractions obtained after $30 \mu \mathrm{M}$ cEPA treatment only and 8 Gy $\mathrm{X}$-ray radiation exposure only were $0.89 \pm 0.08$ and $0.12 \pm 0.01$ for HCT116 cells, respectively. As shown in Fig. 4B, cEPA exposure for $48 \mathrm{~h}$ after irradiation [i.e., 'post-irradiation' = (a) of Fig. 4A] resulted in an increase in radiation-induced cell killing for HCT116 cells, and the surviving fraction was $0.017 \pm 0.002$; therefore, the survival rate of radiosensitive enhancement was $>7$. Furthermore, treatment combining cEPA with radiation therapy was enhanced with the cEPA dose, and $40 \mu \mathrm{M}$ cEPA showed an approximately 10-fold reduction in clonogenic survival compared with the control (0 $\mu \mathrm{M}$ cEPA) (Fig. 4C). In this treatment protocol, when cEPA was treated for $48 \mathrm{~h}$ with radiation 24 or $48 \mathrm{~h}$ after cEPA treatment ['mid-irradiation' = (b) or 'pre-irradiation' = (c) in Fig. 4A, respectively], the radiosensitizing effect had no influence compared with no treatment with cEPA. These data indicate that radiosensitization induced by cEPA is mediated through a post-irradiation process or event.

Effect of cEPA on enhancement of radiation-induced apoptosis. X-ray radiation is known to be a strong inducer of apoptosis (33). To examine whether susceptibility to apoptosis can be a determinant of cEPA treatment, the effect of cEPA on radiation-induced apoptosis in HCT116 cells was investigated using flow cytometry. In this experiment, the three combinations of $30 \mu \mathrm{M}$ cEPA and 8 Gy X-ray irradiation were the same schedules as in Fig. 4A (a-c). After cells were treated with cEPA for $48 \mathrm{~h}$ with irradiation, flow cytometric analysis was performed instead of the clonogenic assay in Fig. 4A. As shown in Fig. 5, a lower concentration of cEPA (i.e., $30 \mu \mathrm{M}$ of the $\mathrm{LD}_{50}$ value of HCT116 cell growth in Fig. 2A) alone did not induce apoptosis, although apoptotic cells were induced by 8 Gy X-ray radiation. Radiationinduced apoptosis depended on the incubation time after irradiation, and cells incubated for $48 \mathrm{~h}$ after irradiation [i.e., (a) of Fig. 4A] showed the highest apoptosis induction compared with other cells incubated for 24 and $0 \mathrm{~h}$ after irradiation; i.e., (b) and (c) of Fig. 4A. In HCT116 cells, DNA damage occurred immediately with irradiation (Fig. 3), although apoptosis was induced $24 \mathrm{~h}$ or later after irradiation. The apoptotic level in cultures receiving combined radiation/ cEPA treatment was greater than in the radiation-only group; therefore, the cEPA-mediated increase in radiosensitivity could be attributed to enhanced susceptibility to apoptosis. 
A

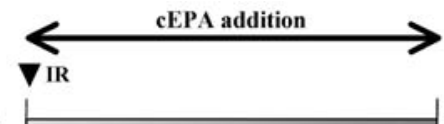

(a)

(b)

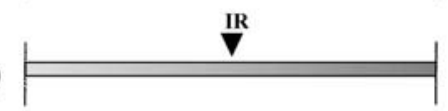

(c)

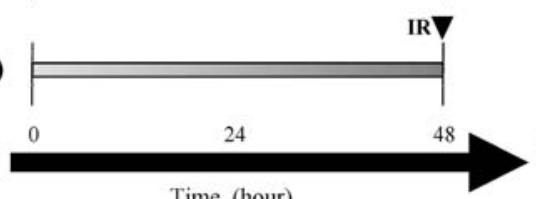

Medium change (without cEPA)

Time (hour 2 weeks incubation Colony count

B

(a)

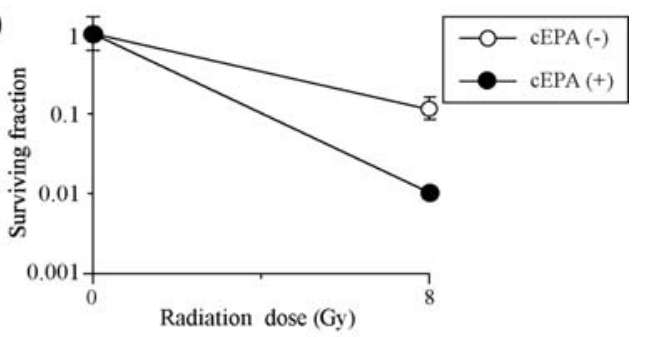

(b)

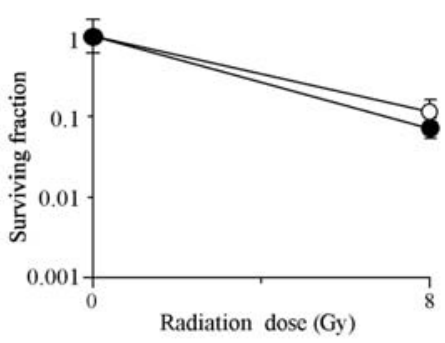

(c)



\section{Discussion}

We reported previously that conjugated PUFA, such as cEPA prepared by alkaline treatment of PUFA, was a two-fold stronger pol inhibitor than normal PUFA (31). cEPA did not influence pol activities from plants and prokaryotes and other DNA metabolic enzyme activities, and no interaction of cEPA with DNA was detected in an independent DNAbinding assay (i.e., Tm of double-stranded DNA measurements) (23). These results suggested that selective inhibitory action by cEPA might be due to specific binding to pol enzymes. Furthermore, the mechanisms by which cEPA suppresses human cancer cell growth were investigated, and it was revealed that the inhibition of pol activity by cEPA influenced not only cell proliferation but also the cell cycle (31). Cell cycle arrest in the G1 phase by cEPA was considered to be induced by the p53/p21 pathway from the ATR-

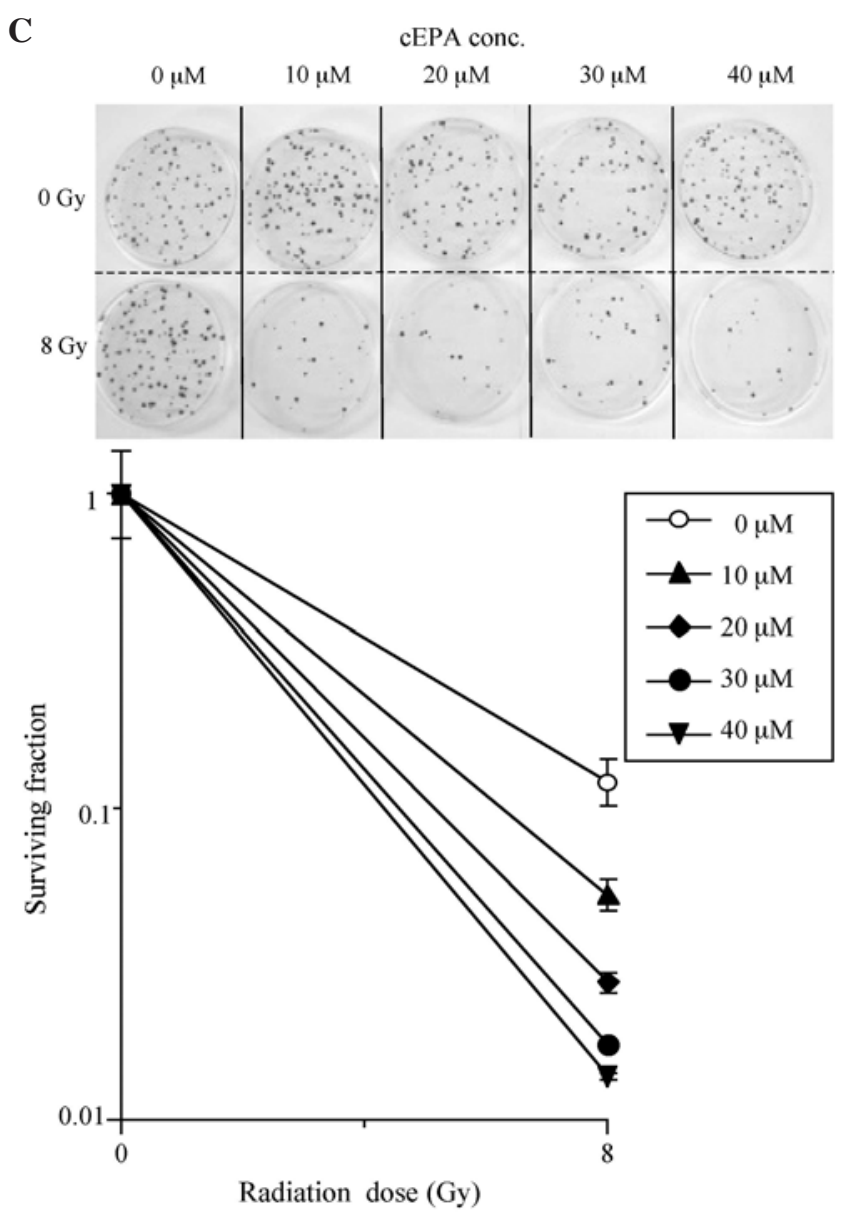

Figure 4. Clonogenic survival of HCT116 cells by combining cEPA and $\mathrm{X}$-ray radiation. (A) Treatment schedules combining $30 \mu \mathrm{M}$ cEPA and 8 Gy of X-ray radiation of human colon carcinoma HCT116 cells. (a), cEPA exposure for $48 \mathrm{~h}$ after irradiation (i.e., 'post-irradiation'); (b), mid-irradiation; and (c), cEPA exposure for $48 \mathrm{~h}$ before irradiation (i.e., 'pre-irradiation'). IR is X-ray irradiation. (B) Survival curves of HCT116 cells by clonogenic assay following the treatment schedules (a) to (c). Cells were added with or without $30 \mu \mathrm{M}$ cEPA. (C) Colony plates of clonogenic assay and survival curves of the HCT116 cells treated by the indicated concentrations of cEPA for $48 \mathrm{~h}$ after radiation; i.e., schedule (a). Values are the means \pm SEM of two independent experiments.

Chk1/2-signaling pathway in HCT116 cells (16). Since cEPA did not influence the proliferation of normal cells (data not shown), cEPA should also be considered the lead compound of a group of potentially useful agents for cancer chemotherapy.

In this study, cEPA (conjugated C20:5 fatty acid) was prepared from EPA by alkaline treatment, as described in Materials and methods, and the chemically synthesized fraction was used. This fraction contained $98 \% \mathrm{cEPA}$, which had conjugated double bonds, but did not contain hydroperoxy- and/or hydroxy-fatty acids (data not shown); however, each cEPA isomer, which has a cis-or trans-double bond compound, was not separated and purified. Jain et al reported that trans-arachidonic acid (C20:4 fatty acid) isomers (especially 5,6-trans-arachidonic acid) showed distinct activity by targeting cell progression through the cell cycle (arrest in the G1 phase) and inducing apoptosis (34). 

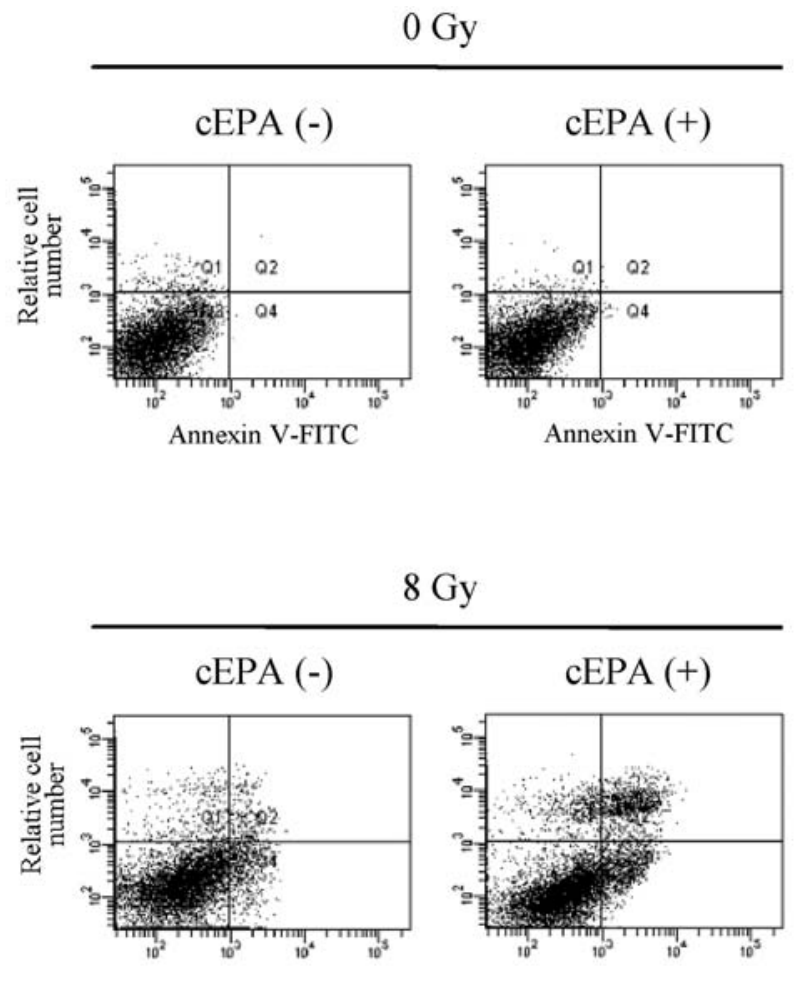

(b)


(c)
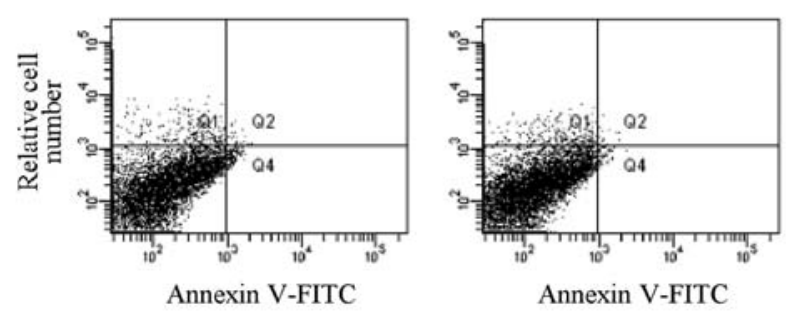

Figure 5. Detection of apoptosis in HCT116 cells by combining cEPA and X-ray radiation. Treatment schedules (a) to (c) combining $30 \mu \mathrm{M}$ cEPA and 8 Gy X-ray radiation of human colon carcinoma HCT116 cells are shown in Fig. 4A. Treated cells were cultured for 48 h, harvested, stained with annexin V, and then analyzed using flow cytometry.

These results suggested that the trans-cEPA isomer in the fraction might have bio-activities, such as pol inhibition, prevention of cancer cell growth, G1 phase arrest of the cancer cell cycle, and apoptosis induction.

Radiotherapy remains a primary cancer treatment modality for solid tumors, and the ability to enhance its efficacy is thus likely to impact a significant number of cancer patients. DNA repair-related pols, especially pol $\beta$, have been shown to be altered in around $30 \%$ of tumors, suggesting a role in tumor formation (35). These changes include overexpression, truncation and mutations modulating the activity of these enzymes and are postulated to influence DNA repair and therefore possibly tumorigenesis (36-38). This is the initial investigation into the combination of radiation and cEPA, which is a selective mammalian pol inhibitor. The results of this study indicate that cEPA enhanced the radiosensitivity of human colon carcinoma HCT116 cells, which inhibited the activities of pols in the cells (Fig. 1), reduced the expression of pols, especially DNA repair-related pols such as pols $B, \delta$ and $\varepsilon$ (Fig. 2), and caused consequent DNA repair inactivation of damaged DNA, including DSBs by X-ray irradiation (Fig. 3). Furthermore, the cell treatment of post-irradiation addition of cEPA showed significantly greater anticancer effects, such as inductions of cancer cell killing and apoptosis, than other combined cEPA/radiation schedules (Figs. 4 and 5). In conclusion, combining selective inhibitors of DNA repair-related pols, such as cEPA, and radiation might have clinical potential as a cancer treatment strategy. 


\section{Acknowledgments}

This work was supported in part by the Academic Frontier Project for Private Universities: matching fund subsidy from the Ministry of Education, Science, Sports and Culture of Japan (MEXT), 2006-2010, (H.Y. and Y.M.). Y.Y. acknowledges a Grant-in-Aid for Young Scientists (B) (no. 21780136) from MEXT. Y.M. acknowledges a Grant-in-Aid for Young Scientists (A) (no. 19680031) from MEXT, and The Salt Science Research Foundation, No. 09S3 (Japan).

\section{References}

1. Kornberg A and Baker TA: DNA replication. 2nd edition. W.D. Freeman and Co., New York, pp197-225, 1992.

2. Hubscher U, Maga G and Spadari S: Eukaryotic DNA polymerases. Annu Rev Biochem 71: 133-163, 2002.

3. Friedberg EC, Feaver WJ and Gerlach VL: The many faces of DNA polymerases: strategies for mutagenesis and for mutational avoidance. Proc Natl Acad Sci USA 97: 5681-5683, 2000.

4. Takata K, Shimizu T, Iwai S and Wood RD: Human DNA polymerase $\mathrm{N}$ (POLN) is a low fidelity enzyme capable of error-free bypass of 5S-thymine glycol. J Biol Chem 281: 23445-23455, 2006.

5. Sakaguchi K, Sugawara F and Mizushina Y: Inhibitors of eukaryotic DNA polymerases. Seikagaku 74: 244-251, 2002.

6. Mizushina Y: Specific inhibitors of mammalian DNA polymerase species. Biosci Biotechnol Biochem 73: 1239-1251, 2009.

7. Mizushina Y, Tanaka N, Yagi H, Kurosawa T, Onoue M, Seto H, Horie T, Aoyagi N, Yamaoka M, Matsukage A, Yoshida S and Sakaguchi K: Fatty acids selectively inhibit eukaryotic DNA polymerase activities in vitro. Biochim Biophys Acta 1308: 256-262, 1996

8. Mizushina Y, Yoshida S, Matsukage A and Sakaguchi K: The inhibitory action of fatty acids on DNA polymerase B. Biochim Biophys Acta 1336: 509-521, 1997.

9. Iigo M, Nakagawa T, Iwahori Y, Asamoto M, Yazawa K, Araki E and Tsuda $\mathrm{H}$ : Inhibitory effects of docosahexaenoic acid on colon carcinoma 26 metastasis to the lung. Br J Cancer 75: 650-655, 1997.

10. Iwamoto S, Senzaki H, Kiyozuka Y, Ogura E, Takada H, Hioki K and Tsubura A: Effects of fatty acids on liver metastasis of ACL15 rat colon cancer cells. Nutr Cancer 31: 143-150, 1998.

11. Lopez A and Gerwick WH: Two new icosapentaenoic acids from the temperate red seaweed Ptilota filicina J. Agardh. Lipids 22: 190-194, 1987.

12. Mikhailova MV, Bemis DL, Wise ML, Gerwick WH, Norris JN and Jacobs RS: Structure and biosynthesis of novel conjugated polyene fatty acids from the marine green alga Anadyomene stellata. Lipids 30: 583-589, 1995.

13. Shultz TD, Chew BP, Seaman WR and Luedecke LO: Inhibitory effect of conjugated dienoic derivatives of linoleic acid and $\beta$-carotene on the in vitro growth of human cancer cells. Cancer Lett 63: 125-133, 1992.

14. Kelly GS: Conjugated linoleic acid: a review. Altern Med Rev 6: 367-382, 2001 .

15. Yonezawa Y, Tsuzuki T, Eitsuka T, Miyazawa T, Hada T, Uryu K, Murakami-Nakai C, Ikawa H, Kuriyama I, Takemura M, Oshige M, Yoshida H, Sakaguchi K and Mizushina Y: Inhibitory effect of conjugated eicosapentaenoic acid on human DNA topoisomerases I and II. Arch Biochem Biophys 435: 197-206, 2005.

16. Yonezawa Y, Hada T, Uryu K, Tsuzuki T, Nakagawa K, Miyazawa T, Yoshida H and Mizushina Y: Mechanism of cell cycle arrest and apoptosis induction by conjugated eicosapentaenoic acid, which is a mammalian DNA polymerase and topoisomerase inhibitor. Int J Oncol 30: 1197-1204, 2007.

17. Yonezawa YK, Sasaki R, Ota Y, Suzuki Y, Fukushima S, Hada T, Uryu K, Sugimura K, Yoshida H and Mizushina Y: Cell cycle arrest triggered by conjugated eicosapentaenoic acid occurs through several mechanisms including G1 checkpoint activation by induced RPA and ATR expression. Biochim Biophys Acta 1790: 339-346, 2009.
18. Haimovitz-Friedman A: Radiation-induced signal transduction and stress response. Radiat Res 150: 102-108, 1998

19. Garcia-Barros M, Paris F, Cordon-Cardo C, Lyden D, Rafii S, Haimovitz-Friedman A, Fuks Z and Kolesnick R: Tumor response to radiotherapy regulated by endothelial cell apoptosis. Science 300: 1155-1159, 2003.

20. Paris F, Fuks Z, Kang A, Capodieci P, Juan G, Ehleiter D, Haimovitz-Friedman A, Cordon-Cardo C and Kolesnick R: Endothelial apoptosis as the primary lesion initiating intestinal radiation damage in mice. Science 293: 293-297, 2001.

21. Li Y, Carty MP, Oakley GG, Seidman MM, Medvedovic M and Dixon K: Expression of ATM in ataxia telangiectasia fibroblasts rescues defects in DNA double-strand break repair in nuclear extracts. Environ Mol Mutagen 37: 128-140, 2001.

22. El-Awady RA, Dikomey E and Dahm-Daphi J: Radiosensitivity of human tumour cells is correlated with the induction but not with the repair of DNA double-strand breaks. Br J Cancer 89: 593-601, 2003.

23. Sakata K, Someya M, Matsumoto Y and Hareyama M: Ability to repair DNA double-strand breaks related to cancer susceptibility and radiosensitivity. Radiat Med 25: 433-438, 2007.

24. Shiloh Y: ATM and related protein kinases: safeguarding genome integrity. Nat Rev Cancer 3: 155-168, 2003.

25. Shiloh Y and Lehmann AR: Maintaining integrity. Nat Cell Biol 6: 923-928, 2004

26. Association of Official Analytical Chemists: Acids (polyunsaturated) in oil and fats. In: Official Methods of Analysis of the Association of Official Analytical Chemists. Helrich K (ed). Association of Official Analytical Chemists, Arlington, pp960-963, 1990.

27. Pitt GAJ and Morton RA: Ultra-violet spectrophotometry of fatty acids. Prog Chem Fats Other Lipids 4: 227-278, 1957.

28. Mosmann T: Rapid colorimetric assay for cellular growth and survival: application to proliferation and cytotoxicity assays. J Immunol Methods 65: 55-63, 1983.

29. Heintel D, Kroemer E, Kienle D, Schwarzinger I, Gleiss A, Schwarzmeier J, Marculescu R, Le T, Mannhalter C, Gaiger A, Stilgenbauer S, Dohner H, Fonatsch C and Jager U: German CLL Study Group. High expression of activation-induced cytidine deaminase (AID) mRNA is associated with unmutated IGVH gene status and unfavourable cytogenetic aberrations in patients with chronic lymphocytic leukaemia. Leukemia 18: 756-762, 2004.

30. Singh NP, McCoy MT, Tice RR and Schneider EL: A simple technique for quantitation of low levels of DNA damage in individual cells. Exp Cell Res 175: 184-191, 1998.

31. Yonezawa Y, Hada T, Uryu K, Tsuzuki T, Eitsuka T, Miyazawa T, Murakami-Nakai C, Yoshida $\mathrm{H}$ and Mizushina Y: Inhibitory effect of conjugated eicosapentaenoic acid on mammalian DNA polymerase and topoisomerase activities and human cancer cell proliferation. Biochem Pharmacol 70: 453-460, 2005.

32. Rogakou EP, Pilch DR, Orr AH, Ivanova VS and Bonner WM: DNA double-stranded breaks induce histone H2AX phosphorylation on serine 139. J Biol Chem 273: 5858-5868, 1998.

33. Blumenstein M, Hossfeld DK and Dührsen U: Indirect radiation leukemogenesis in DBA/2 mice: increased expression of B2 repeats in FDC-P1 cells transformed by intracisternal A-particle transposition. Ann Hematol 76: 53-60, 1998.

34. Jain K, Roy U, Ardelt B, Krishna UM, Falck JR, Pozarowski P, Kunicki J, Darzynkiewicz Z and Balazy M: 5E, 8Z, 11Z, 14Zeicosatetraenoic acid, a novel trans isomer of arachidonic acid, causes G1 phase arrest and induces apoptosis of HL-60 cells. Int J Oncol 27: 1177-1185, 2005.

35. Albertella MR, Lau A and O'Connor MJ: The overexpression of specialized DNA polymerases in cancer. DNA Repair (Amst) 4: 583-593, 2005.

36. Lang T, Maitra M, Starcevic D, Li SX and Sweasy JB: A DNA polymerase $\beta$ mutant from colon cancer cells induces mutations. Proc Natl Acad Sci USA 101: 6074-6079, 2004.

37. Starcevic D, Dalal S and Sweasy JB: Is there a link between DNA polymerase $\beta$ and cancer? Cell Cycle 3: 998-1001, 2004.

38. Sweasy JB, Lang T, Starcevic D, Sun KW, Lai CC, Dimaio D and Dalal S: Expression of DNA polymerase \{beta\} cancerassociated variants in mouse cells results in cellular transformation. Proc Natl Acad Sci USA 102: 14350-14355, 2005. 